\title{
Strain engineering via regulatory noncoding RNAs: not a one-blueprint-fits-all
}

\author{
Seung Hee $\mathrm{Cho}^{4}$, Katie Haning ${ }^{2}$, and Lydia M. Contreras ${ }^{1,2 *}$ \\ ${ }^{1}$ Institute for Cellular \& M olecular Biology, The University of Texas at Austin,M olecular Biology Building, 2500 \\ Speedway Stop A4800, Austin, TX, USA 78712. \\ ${ }^{2}$ M cKetta Department of Chemical Engineering, Cockrell School of Engineering, The University of Texas at Austin, \\ 200 E. Dean Keeton St. Stop C0400, Austin, TX, USA 78712.
}

*Correspondence: Lydia M . Contreras, M cKetta Department of Chemical Engineering, Cockrell School of Engineering, The University of Texas at Austin, 200 E Dean Keeton St. Stop C0400, Austin, TX, USA 78712. Icontrer@che.utexas.edu (512) 471-2453

†These authors contributed equally to this work.

\begin{abstract}
Increasing demands for efficient, sustainable chemical production continue to motiate engineering of microbial strains. Noncoding RNAs (ncRNAs) represent a class of powerful regulators of cellular processes and are emerging as significant tools for strain engineering, particularly for complex phenotypes. Current strategies include adjusting expression levels of natural ncRNAs and developing synthetic ncRNAs to target specific genes. In this review, wesummarize and analyze the effectiveness of the design blueprints for a variety of natural and synthetic ncRNA systems recently reorted in the literature to offer a concise and easy to read engineering guide to exploitingtrans-regulatory ncRNAsfor strain engineering.
\end{abstract}

\section{Introduction}

With rising demands of efficiency, environmental care, and sustainability, the use of microbes as chemical factories is increasingly attractive. As regulatory noncoding RNAs (ncRNAs) continue to be discovered in organisms of traditionally high relevance to biotechnology, understanding of and exploitation of natural cellular regulation to help achieve production and efficiency goals have expanded. These ncRNAs are $\sim 50-300$ nt transcripts that act as regulators of mRNA and protein expression, typically by blocking translation or changing stability [1]. In bacteria, small ncRNAs have 
been highlighted as powerful tools due to their regulatory roles in cellular pathways [2-5]. Cis-regulatory ncRNAs act on regions within the same RNA transcript while trans-regulatory ncRNAs regulate separate RNA transcripts or proteins [5]. Riboswitches are a prominent class of cis-regulatory ncRNAs typically in 5'- or 3'-untranslated regions (UTRs) of RNA transcripts with great potential for local control of gene expression in metabolic engineering efforts; these have recently been reviewed [6] and are not discussed here. So far, engineering strategies involving trans-regulatory ncRNAs fall into two general approaches as shown in Figure 1: (A) altering expression of well-characterized natural ncRNAs to induce enhanced regulatory effects on protein expression levels (potentially in multiple pathways) and (B) designing synthetic ncRNAs to knockdown expression of individual proteins.

In this review, we offer a concise guide to exploiting trans-regulatory ncRNAs for strain engineering by considering the effectiveness of the design blueprints that have been recently proposed for a variety of natural and synthetic ncRNA systems (Table 1). M ore historical accounts of ncRNAs and their applications are available $[4,5,7]$. Due to the absence of RNA interference in bacterial systems, the use of synthetic ncRNAs shows significant promise as an effective gene-silencing tool. M ost engineering efforts have focused so far on the exploitation of ncRNA translational repression mechanisms, preventing translation by blocking the ribosome-binding site (RBS). The limited exploitation of ncRNAs stems from the challenge that much remains unknown about the networks of mRNAs, proteins, and transcriptional factors that are regulated in response to environmental changes. As a growing number of ncRNA mechanisms continue to be uncovered, applications for strain engineering will likewise continue to expand. For example, target activating ncRNAs are now known to bind at 5'- or 3'-UTRs of their targets to allow accessibility of a previously blocked RBS or to increase the stability of the target transcript $[8,9]$. These activating mechanisms may provide unique protein overexpression possibilities for strain engineering.

\section{Exploitation of naturally discovered ncRNAs: construction of overexpression and deletion strains}

Hundreds of natural ncRNAs have been discovered throughout bacteria, largely enabled by highthroughput sequencing technologies $[4,10,11]$. In E. coli alone, over a hundred are now confirmed. M any ncRNAs are known to impact expression of multiple mRNA targets, some of which have been biochemically and genetically identified and others yet to be uncovered. Importantly, a significant number of these ncRNAs (particularly in Gram-negative bacteria) depend on the RNA-binding protein $\mathrm{Hfq}$ as a cofactor that enables mRNA targeting $[12,13]$. Hfq homologs are widespread across bacterial species, although still undetected in many species [14].

Recently, natural ncRNAs have been exploited to increase acid tolerance in E. coli [15]. These efforts were largely enabled by the fact that multiple Acid Resistance (AR) systems in E. coli are wellcharacterized and considered global stress response systems, encompassing a wide variety of genes. For instance, AR1 depends on the RpoS sigma factor that directly or indirectly regulates about 500 genes $[16,17]$. Given this dependence on RpoS, engineering efforts on the AR1 system in E. coli have focused on manipulating RpoS levels. Interestingly, simple overexpression of rpoS by removal of its natural 5'UTR does not significantly improve acid tolerance and is not sufficient to fully induce the genes it regulates [18]. The inability to use conventional overexpression strategies to increase levels of RpoS is not surprising given that expression of this protein is tightly regulated at multiple levels by a variety of ncRNAs (e.g. DsrA, RprA, and ArcZ) that stimulate rpoS translation through its 5'-UTR [18]. This is an 
interesting case in which the cis-regulatory ncRNA (5'-UTR) blocks the RBS until the trans-regulatory ncRNAs (DsrA, RprA, ArcZ) bind to complementary nucleotide sequences in the cis-regulator and free the RBS to allow translation.

Since affecting a complex phenotype like acid tolerance is well-suited for trans-regulatory ncRNA engineering, a new strategy overexpressed the three ncRNAs known to up-regulate RpoS levels (instead of overexpressing RpoS directly) [15]. All three overexpression strains (RprA, ArcZ, and DsrA under their native promoters) showed increased survival percentage after $1 \mathrm{~h}$ growth in acidified media ( $\mathrm{pH} 2.5)$ with 3-, 5-, and 106-fold improvements over the empty plasmid control strain, respectively. Furthermore, a triple overexpression strain (combination of all three ncRNAs) showed an impressive 8500-fold improvement in cell survival after acid stress, demonstrating a supra-additive effect of combinatorial overexpression that cannot be solely attributed to simple increase in RpoS protein expression levels.

Importantly, the engineering of ncRNAs to improve survival under acid stress set a precedent for using natural ncRNA regulators to tune expression of entire sets of pathways. However, unlike this demonstration, the vast majority of ncRNAs have not been characterized, leaving their mRNA targets and mechanisms of action unknown, particularly beyond E. coli. For example, in Streptomyces coelicolor, no natural ncRNAs had been functionally characterized and no $\mathrm{Hfq}$ homologs were known, but a natural cis-encoded antisense RNA was overexpressed and phenotypic impacts on antibiotic production were observed [19]. An additional challenge with this overexpression approach is the risk of expressing ncRNAs at non-native levels given the variety of pathways that can be negatively impacted.

As a demonstration that effective engineering of ncRNA overexpression could be achieved successfully under a non-native promoter, recent work showed that constitutive overexpression of ncRNA RyhB in E. coli DALA under the RNA polymerase binding region of the $P_{B A D}$ promoter enabled production of $16 \%$ more 5-aminolevulinic acid (ALA), as listed in Table 1 [20]. This ncRNA approach was motivated by the lack of success with traditional methods involving gene expression of selected enzymes given the complex nature of this pathway and the synergistic interdependence of the enzymes involved. RyhB had been shown to enable cell survival in iron-deficient environments by down-regulating iron-containing proteins to free iron for other essential cellular functions [21]. RyhB was also known to down-regulate four enzymes in the TCA-heme pathway with two additional computationally predicted targets (hemH and hemB).

To date, knockouts (or knockdowns) of natural ncRNAs are not widely used as engineering strategies, but have been performed with the motivation of characterizing the functions of ncRNAs as they are discovered [22-24]. This approach is particularly common for bacterial pathogens, for which some ncRNA knockout strains can have differential ability to infect their hosts [25,26]. The variety of bacterial ncRNA roles in virulence have been well reviewed in recent years [27-29], including within the particular context of Listeria [30], M ycobacterium [31], Pseudomonas [32], Staphylococcus [33], Streptococcus [34], and Vibrio [35]. The lack of ncRNA knockouts for strain engineering is not surprising as the nature of ncRNA regulation is dynamic with respect to cellular stresses and growth phases; as such, simple knockouts may not be beneficial in all conditions throughout cellular growth. Additionally, the necessary genetic tools for ncRNA deletions are more complex than plasmid overexpression approaches, limiting the screening of combinatorial effects involving multiple ncRNAs. 


\section{Design of synthetic ncRNAs: modular blueprints inspired by natural mechanisms}

Soon after antisense RNAs were discovered to bind complementary to mRNAs and regulate their translation [36], ncRNAs were constructed to accomplish this regulation artificially in E. coli $[37,38]$ and in a variety of organisms including Mycobacterium [39,40], Clostridium [41], Staphylococcus [42], Lactobacillus [43], and Bacillus [44]. Although the efficiencies were initially low and highly genedependent, the potential of using antisense RNAs to knockdown (but not completely knockout) essential genes has motivated a variety of new designs to express these antisense binding sequences [45]. As shown in Figure 2, a basic modular design that surfaced for engineering efficient expression of transregulatory ncRNAs includes: (i) a promoter, (ii) an antisense binding domain to a target mRNA, (iii) a scaffold for stability and/or Hfq binding, and (iv) a terminator [46-49]. As we highlight below and in Table 1, a variety of synthetic antisense ncRNA strategies has surfaced within this basic architectural blueprint.

To express a synthetic ncRNA in vivo, they are typically enco ded on a plasmid with a promoter region upstream of the ncRNA to initiate transcription. Selection of appropriate (i.e. tightly regulated promoters) promoters is a key for the effective inhibition of target mRNA expression [46,50,51]. Regulatory promoters (M odule 1 in Figure 2) are especially useful as the expression can be turned on and off with ligand inputs or with temperature [47]. As shown in Table 1, recent studies employ a variety of promoters. Importantly, the transcription start site (TSS) of the selected promoter should be known. In at least one study, different types of promoters ( $P_{T e t}, P_{T 7}$ and $\left.P_{T r c}\right)$ were tested and selected for the efficient gene silencing according to the sensitivity of the target mRNA [50]. An alternative to plasmid expression has been to deliver the ncRNAs via M 13 phage infection [52], as shown in E. coli for engineering antibiotic sensitivity (Table 1). An optimization challenge that arose from this study is the need for appropriate copy numbers with phage infection.

Downstream of the promoter, a stretch of nucleotides is designed for antisense base pairing with a target mRNA near its start codon (M odule 2 in Figure 2). This antisense binding region is central to the mechanism of ncRNA translational repression of the mRNA. The most efficient length and location of binding to the target mRNA varies from target to target. One approach to find the optimal binding sequence is by randomly screening a library of synthesized ncRNAs using a GFP reporter system $[53,54]$. As illustrated in Module 3 (Figure 2A), this approach was used to identify binding sequences with the highest repression efficiencies for OmpF, FliC, and RecA in E. coli. In the case of RecA, this screening process was used to uncover key regions within the target recA mRNA that could be most affected by mutations to disrupt gene expression. Indeed, after using IntaRNA [55] to predict interactions between the synthetic ncRNA and recA, targeted mutations to the Shine-Dalgarno (SD) sequence of recA showed $86 \%$ of repression for RecA (improved from $78 \%$ from the random screen).

Recently, a systematic rational design process of the antisense binding region has been reported [56,57]. In this work, instead of a random library of sequences, various target-binding sequences from the transcription initiation region (TIR) (including RBS and SD sequences to outside of TIR regions) were screened for efficient repression. In addition, binding energies were evaluated to confirm the correlation with repression capability. Here, target-binding regions containing the TIR were selected due to their highest repression capabilities. This result suggested that prediction of binding energy (less than $20 \mathrm{kcal} / \mathrm{mol}$ ) can be used one of the parameters for selecting target binding sequence. Using this strategy, repression of the tyrR and csrA genes involved in tyrosine biosynthesis pathway resulted in the highest tyrosine production ( $2 \mathrm{~g} / \mathrm{L}$ ) achieved to date in $\mathrm{E}$. coli. In addition, use of these synthetic ncRNAs enabled identification of new gene targets for engineering cadaverine production (Table 1). These 
authors applied the same design process to develop E. coli strains for short-chain alkanes and phenol production in combination with traditional metabolic engineering strategies $[58,59]$.

Antisense binding regions may be attached to scaffolds derived from natural ncRNAs (M odule 3 in Figure 2) for structural stability and for recruitment of the Hfq protein to mediate binding to the mRNA target $[48,53]$. Natural ncRNA scaffolds (DsrA, GcvB, MicF, and Spot42) have been fused to the target binding sequence screened for repression efficiency and engineered for $\mathrm{Hfq}$ binding through mutational analysis increasing predicted ncRNA secondary structure stability [60]. In another study, 101 known ncRNAs were analyzed, leading to the selection of $\mathrm{MicC}$, a natural ncRNA involved in OmpC outer membrane protein translation, as a synthetic ncRNA scaffold [56]. The M icC scaffold was used in several following studies as shown in Table 1 including tyrosine, cadaverine, phenol and $\mathrm{N}$-acetylglucosamine production. This scaffold is particularly attractive as its targeting and $\mathrm{Hfq}$ binding sequences are well known and it is thought to bind only one target. Although computational target prediction programs for ncRNA-mRNA pairs can effectively predict real targets, experimental confirmation of these predictions can be slow, limiting the use of ncRNAs that are suspected to regulate multiple targets [61].

The first report of ncRNAs for strain engineering in Bacillus subtilis also used this blueprint (Figure 2A) with the E. coli M icC scaffold [62]; in this case, Hfq was expressed from a plasmid to overcome the lack of $\mathrm{Hfq}$ in Bacillus. The success of this strategy was reflected in the $134 \%$ improvement in $\mathrm{N}$ acetylglucosamine production shown by the ncRNA-engineered strain over the B. subtilis control (Table 1). Still, the lower repression efficiency and lower overall productivity in B. subtilis compared to E. coli demonstrates the need to further optimize this blueprint for organisms that natural lack Hfq. Limited information about ncRNAs in non-model organisms hinders wider exploitation of these powerful tools.

An alternative scaffold architecture has been pursued with the development of paired-terminus antisense RNAs (PTasRNAs) [50], which have complementary $38 \mathrm{nt}$ flanking regions on each side of the antisense targeting region to form a stable hairpin as illustrated in Figure 2B. PTasRNAs have been successful in optimizing pyruvate production, fatty acid synthesis, and antibacterial sensitivity in E. coli [46,49,63-65] and inhibition of actinorhodin biosynthesis in Streptomyces coelicolor [66]. As noted in the Streptomyces study, natural ncRNA mechanisms are largely unknown, making further optimization of the ncRNA design challenging [66]. For example, because there are no Hfq homologs known in this organism [19], it is unclear whether a scaffold mimicking natural ncRNA recruitment of Hfq would increase efficiency or if the stability provided by the PTasRNA structure (Figure 2B) is sufficient. Importantly, the PTasRNA strategy has also been shown effective in silencing multiple genes in combination [49].

M ost recently, a new class of synthetic RNAs, small transcription activating RNAs (STARs) [67], has been engineered as antisense to a synthetically constructed terminator-like hairpin that is placed upstream of a target gene. In this design, the hairpin prevents gene transcription unless it is disrupted by the STAR (various lengths, 17-60 nt); in this case, the hairpin is opened to allow transcription. A key design parameter of STARs is the selection of the hairpin sequence and length coupled to the STAR length. This system parallels translational control schemes that have been reported in the context of SD-antiSD hairpins that act as riboregulators at the $5^{\prime}$ of a target gene $[68,69]$. STARs have been designed to successfully target natural terminators in E. coli, but given that these are at the end of genes, they have undetectable effects on expression of the surrounding genes. Although they do not have a clear role in metabolic engineering at this point, STARs show promise for developing RNA-only logic networks [70]. 


\section{Conclusion}

As indicated in Table 1, current engineering efforts have mostly focused on model organisms in wellcharacterized pathways. Limited information about ncRNAs in non-model organisms has hindered wider exploitation of these powerful tools. However, there is great potential to adapt these modular ncRNA designs to target the same pathways in a variety of industrially relevant organisms. Even in E. coli, mechanisms of ncRNA action on their targets are not fully characterized, preventing rational ncRNA design strategies. Lack of understanding of ncRNA mechanisms in non-model organisms has also limited the design of synthetic ncRNAs to include scaffolds for cofactor binding as the chaperoning role of $\mathrm{Hfq}$ in mediating ncRNA-target binding is not clear in other organisms (particularly in Gram-positive bacteria) [71]. As such, current blueprints that involve $\mathrm{Hfq}$ are not as effective in all bacteria.

Another major hurdle is the characterization of precise regions where ncRNAs bind their targets in vivo. Studies of native or synthetic antisense ncRNAs have demonstrated that target-binding region is crucial for efficient regulation of target mRNAs. Although computational target prediction programs for ncRNAmRNA pairs can effectively predict real targets, experimental confirmation of these predictions can be slow, leaving false positive rates of these programs unknown [61]. In this capacity, thermodynamics analysis has uncovered strong positive correlations between ncRNA-target binding energies and gene repression [57]. Likewise, information regarding binding energy calculations has been valuable for further enhance knockdown efficiency by mutagenesis approaches that fine-tune target binding regions on the ncRNA [56]. We suspect that recent in vivo structural analysis methods will be of high benefit to this problem $[69,72,73]$.

Finally, methods to more efficiently use "omics" datasets would allow genome-wide insights into the ncRNA strain engineering process. As more natural ncRNAs are discovered to be relevant to industrial phenotype goals, combinations of ncRNA overexpressions and deletions in a single strain could be a powerful strain development approach. Combined with traditional metabolic engineering approaches, these strains may produce currently unachievable phenotypes.

\section{Acknowledgements}

This work was supported by the National Science Foundation (NSF) Graduate Research Fellowship Program (DGE-1110007) to Katie Haning as well as the Welch Foundation (F-1756) and NSF (CBET1254754) to Lydia M. Contreras.

\section{Figures}

Figure 1. General engineering approaches of noncoding RNAs. (A) Altering levels of selected mRNA targets by overexpression or deletion of natural ncRNAs (green). Some mRNA targets may be known (red) while others may be undiscovered and uncharacterized (black). Overexpression of ncRNAs from plasmids with non-natural promoters (black arrow) and of cofactors known to mediate ncRNA-target interactions (black triangle) have been used to observe the effect of ncRNAs on target proteins and enzymes in a diversity of pathways. Deletion of ncRNAs from genomic DNA has been used to confirm the regulatory effects on the target genes. Both overexpression and deletion strategies can alter protein expression levels, potentially in multiple cellular pathways. (B) Designing synthetic ncRNAs to knockdown expression of individual proteins by blocking translation of mRNA targets (red). Basic strategies include an antisense-binding region (green) that binds to the RBS (black square) or another 
target region and a scaffold (yellow) for stability and/or to facilitate cofactor binding. This strategy is effective for knocking down known mRNA targets.

Figure 2. Design strategies of synthetic noncoding RNAs for effective gene regulation. M odular design of synthetic ncRNAs: M odule 1 is the selection of a known promoter. M odule 2 comprises of targetbinding sequence that is antisense to a ribosomal binding sequence. Potential target binding sequences are tested for the effective gene knockdown. Selected binding sequences can be further mutagenized to achieve higher effectiveness. M odule 3 represents a scaffold for the stabilization of ncRNAs. A scaffold can be chosen from well-known natural ncRNAs (A) such as Spot42, DsrA, M icC, and MicF to recruit additional cofactors ( $\mathrm{Hfq}$ ). Alternatively, (B) PTasRNAs have been designed with complementary $38 \mathrm{nt}$ flanking regions, on each side of the antisense targeting region to form a stable hairpin. M odule 4 involves natural terminators. Each module can be engineered to fine-tune the action of synthetic ncRNAs for effective target gene regulation. 


\section{Tables and boxes}

\section{Table 1. Examples of natural and synthetic ncRNAs used for engineering metabolic pathways.}

\begin{tabular}{|c|c|c|c|c|c|c|c|c|c|c|}
\hline phenotype objective & organism & ncRNA type & $\begin{array}{l}\text { ncRNA targets } \\
\text { (mRNA) }\end{array}$ & promoter & $\begin{array}{l}\text { binding } \\
\text { sequence on the } \\
\text { target }\end{array}$ & scaffold(s) & terminator & $\begin{array}{l}\text { Hfq- } \\
\text { dependent? }\end{array}$ & strain performance & Ref \\
\hline acid resistance & E. coli & $\begin{array}{l}\text { natural DsrA, } \\
\text { RprA, ArcZ }\end{array}$ & $\mathrm{rpoS}^{1}$ & natural & natural & natural & natural & yes & $\begin{array}{l}\text { 8502-fold increase in acid } \\
\text { stress survival (after triple } \\
\text { sRNA overexpression) }\end{array}$ & [15] \\
\hline $\begin{array}{l}\text { 5-aminolevulinic acid } \\
\text { production }\end{array}$ & E. coli & natural RyhB & $\begin{array}{l}\text { hemBH, } \\
\text { acnAB, sdhAB, } \\
\text { fumA, cydAB }\end{array}$ & $P_{B A D}$ & natural & natural & natural & yes & $\begin{array}{l}16 \% \text { increase in } 5- \\
\text { aminolevulinic acid } \\
\text { production }\end{array}$ & [20] \\
\hline RNaseE reduction & E. coli & $\begin{array}{l}\text { traditional } \\
\text { asRNA }\end{array}$ & rne & $P_{\text {tet }}$ & $\begin{array}{l}\text { RBS to the 51bp } \\
(-32 \text { bp to }+51) \text { of } \\
\text { rne transcript }\end{array}$ & $\mathrm{N} / \mathrm{A}$ & $\mathrm{t}_{0}$ & no & $\begin{array}{l}35 \% \text { reduction in Rnase } \\
\text { level }\end{array}$ & [74] \\
\hline RpoS repression & E. coli & $\begin{array}{l}\text { traditional } \\
\text { asRNA }\end{array}$ & rpos & $\mathrm{P}_{\mathrm{t} 7}$ & $\begin{array}{l}\text { randome library } \\
\text { screening }\end{array}$ & $\mathrm{N} / \mathrm{A}$ & $\mathrm{T7}$ & no & RpoS repression & [75] \\
\hline $\begin{array}{l}\text { Cobalamine (Vitamin } \\
\text { B12) production }\end{array}$ & $\begin{array}{l}\text { B. mega- } \\
\text { terium }\end{array}$ & $\begin{array}{l}\text { traditional } \\
\text { asRNA }\end{array}$ & hemZ & $P_{x y \mid A}$ & $\begin{array}{l}82 \mathrm{nt} \text { upstream } \\
\text { of start codon to } \\
\text { the first } 47 \mathrm{nt} \text { of } \\
\text { hem }\end{array}$ & $\mathrm{N} / \mathrm{A}$ & $\mathrm{N} / \mathrm{A}$ & no & $\begin{array}{l}20 \% \text { increase in vitamin B12 } \\
\text { production }\end{array}$ & [44] \\
\hline butyrate formation & $\begin{array}{l}\text { C. Aceto- } \\
\text { butylicum }\end{array}$ & $\begin{array}{l}\text { traditional } \\
\text { asRNA }\end{array}$ & bk, ptb & $P_{p t b}$ & $\begin{array}{l}\text { 102-nucleotide } \\
\text { asRNA with } 87 \% \\
\text { complementarity } \\
\text { /698-nucleotide } \\
\text { asRNA with } 96 \% \\
\text { complementarity }\end{array}$ & $\mathrm{N} / \mathrm{A}$ & $\begin{array}{l}\text { adc } \\
\text { terminator }\end{array}$ & no & $\begin{array}{l}50 \% \text { increase in acetone } \\
\text { and } 35 \% \text { in butanol/ } 300 \% \\
\text { increase in lactate } \\
\text { dehydrogenase activity (no } \\
\text { change in butyrate } \\
\text { formation) }\end{array}$ & [41] \\
\hline $\begin{array}{l}\text { S-adenosylmethionine } \\
\text { production }\end{array}$ & E. coli & $\begin{array}{l}\text { synthetic multi- } \\
\text { domain scaffold }\end{array}$ & $\begin{array}{l}\text { aroE, proA, } \\
\text { ilvC, } \\
\text { proC,argC,rfp }\end{array}$ & $\mathrm{Pr}_{\mathrm{r}}$ & $\begin{array}{l}\text { TIR of target } \\
\text { mRNA }\end{array}$ & MicC & $\mathrm{T7}$ & yes & $\begin{array}{l}70 \% \text { increase in S- } \\
\text { adenosylmethyl production }\end{array}$ & [76] \\
\hline uidA gene silencing & E. coli & $\begin{array}{l}\text { synthetic multi- } \\
\text { domain scaffold }\end{array}$ & uidA & $\mathrm{P}_{\mathrm{tac}}$ & $\begin{array}{l}5^{\prime} \text { UTR } \\
\text { containing } \\
\text { region }\end{array}$ & $\begin{array}{l}\text { RyhB, Spot } 42 \\
\text { DsrA and OxyS }\end{array}$ & $\begin{array}{l}\text { natural } \\
\text { from } \\
\text { scaffold }\end{array}$ & yes & $\begin{array}{l}\text { 4- to 7-fold repression of } \\
\text { target genes }\end{array}$ & $\begin{array}{l}\text { Man } \\
201 \\
1\end{array}$ \\
\hline decreased cell motility & E. coli & $\begin{array}{l}\text { synthetic multi- } \\
\text { domain scaffold }\end{array}$ & ompF, flic & $P_{B A D}$ & $\begin{array}{l}20-30 \mathrm{nt} \text { random } \\
\text { library screen }\end{array}$ & $\begin{array}{l}\text { DsrA, GcvB, } \\
\text { MicF, Spot42 }\end{array}$ & $\begin{array}{l}\text { natural } \\
\text { from } \\
\text { scaffold }\end{array}$ & yes & $\begin{array}{l}\text { decreased motility } \\
\text { (qualitative assay) }\end{array}$ & [53] \\
\hline $\begin{array}{l}\text { decreased cell motility, } \\
\text { increased } \\
\text { fluloroquinone } \\
\text { antibiotic sensitivity }\end{array}$ & E. coli & $\begin{array}{l}\text { synthetic multi- } \\
\text { domain scaffold }\end{array}$ & recA & $P_{\text {Ltet01 }}$ & $\begin{array}{l}20-30 \mathrm{nt} \text { random } \\
\text { library screen }\end{array}$ & Spot42 & $\begin{array}{l}\text { natural } \\
\text { from } \\
\text { scaffold }\end{array}$ & yes & $\begin{array}{l}\text { decreased motility, increase } \\
\text { ciprofloxacin sensitivity } \\
\text { (qualitative assays) }\end{array}$ & [54] \\
\hline $\begin{array}{l}\text { short-chain alkane } \\
\text { production }\end{array}$ & E. coli & $\begin{array}{l}\text { synthetic multi- } \\
\text { domain scaffold }\end{array}$ & $\mathrm{fabH}$ & $P_{\text {tac }}$ & TIR region & MicC & $\mathrm{T} 1 / \mathrm{TE}$ & yes & $\begin{array}{l}\text { increase in short-chain fatty } \\
\text { acids }\end{array}$ & $\begin{array}{l}\text { Choi } \\
201 \\
3\end{array}$ \\
\hline tyrosine production & E. coli & synthetic multi- & tyrR, csrA, pgi, & $P_{R}$ & 24 nt near TIR & $\mathrm{MicC}$ & $\mathrm{T} 1 / \mathrm{TE}$ & yes & $2 \mathrm{~g} / \mathrm{L}$ tyrosine produced & [56] \\
\hline
\end{tabular}




\begin{tabular}{|c|c|c|c|c|c|c|c|c|c|c|}
\hline & & domain scaffold ${ }^{2}$ & $\mathrm{ppc}$ & & & & & & $\begin{array}{l}\text { (equivalent to traditionally } \\
\text { engineered strains) }\end{array}$ & \\
\hline cadevarine production & E. coli & $\begin{array}{l}\text { synthetic multi- } \\
\text { domain scaffold }\end{array}$ & 130 targets & $P_{R}$ & 24 nt near TIR & MicC & $\mathrm{T} 1 / \mathrm{TE}$ & yes & $\begin{array}{l}55 \% \text { increase in cadaverine } \\
\text { production over engineered } \\
\text { strain XQ56 }\end{array}$ & [56] \\
\hline phenol production & E. coli & $\begin{array}{l}\text { synthetic multi- } \\
\text { domain scaffold }\end{array}$ & $\operatorname{csr} A$, tyrR & $P_{R}$ & $24 \mathrm{nt}$ near TIR & MicC & $\mathrm{T} 1 / \mathrm{TE}$ & yes & $\begin{array}{l}3 \times \text { greater phenol titer than } \\
\text { previous best reported } \\
\text { microbial fermentation }\end{array}$ & [59] \\
\hline $\begin{array}{l}\mathrm{N} \text {-acetylglucosamine } \\
\text { production }\end{array}$ & B. subtilis & $\begin{array}{l}\text { synthetic multi- } \\
\text { domain scaffold }\end{array}$ & pfk, glmM & $\mathrm{P}_{\mathrm{spac}}$ & $24 \mathrm{nt}$ near TIR & MicC & $\mathrm{T}_{\text {spovg }}$ & yes $^{3}$ & $\begin{array}{l}134 \% \text { increase over B. } \\
\text { subtilis control }\end{array}$ & [62] \\
\hline $\begin{array}{l}\text { silencing antibiotic } \\
\text { resistance }(\mathrm{Cm}, \mathrm{Kan})\end{array}$ & E. coli & $\begin{array}{l}\text { synthetic multi- } \\
\text { domain scaffold }\end{array}$ & cam, nptll & $P_{R}$ & 24 nt near TIR & MicC & $\mathrm{T} 1 / \mathrm{TE}$ & yes & $\begin{array}{l}>99 \% \text { colonies sensitive to } \\
\text { high Kan/Cm concentrations }\end{array}$ & [52] \\
\hline $\begin{array}{l}\text { sensitization to } \\
\text { antibacterial essential } \\
\text { oils eugenol and } \\
\text { carvacrol }\end{array}$ & E. coli & PTasRNA & yidC, murA & $\mathrm{P}_{\mathrm{trc}}$ & $\begin{array}{l}\text { 130-134 nt near } \\
\text { TIR }\end{array}$ & paired-termini & $T_{\text {rrnB }}$ & no & $\begin{array}{l}\text { min inhibitory } \\
\text { concentration reduced from } \\
2.5 \text { to } 0.156 \mathrm{mg} / \mathrm{mL}\end{array}$ & [65] \\
\hline pyruvate accumulation & E. coli & PTasRNA & 71 targets & $P_{\text {trc }}$ & $70-160 \mathrm{nt}$ & paired-termini & $T_{\text {rrnB }}$ & no & $\begin{array}{l}25 \mathrm{~g} / \mathrm{L} \text { pyruvate produced } \\
\text { (equivalent to traditionally } \\
\text { engineered strains) }\end{array}$ & [49] \\
\hline $\begin{array}{l}\text { (2S)-naringenin } \\
\text { Production }\end{array}$ & E. coli & PTasRNA & fabBF & $P_{\text {trc }}$ & $\begin{array}{l}\text { 148-245 nt near } \\
\text { TIR }\end{array}$ & paired-termini & $T_{\text {rrnB }}$ & no & $\begin{array}{l}431 \% \text { increase of }(2 S)- \\
\text { naringenin production }\end{array}$ & [63] \\
\hline acetate production & E. coli & PTasRNA & ackA & $P_{\text {trc, }}, P_{\text {araBAD }}$ & 147bp near TSS & paired-termini & $T_{\text {rrnB }}$ & no & $\begin{array}{l}48 \% \text { reduction in ackA } \\
\text { expression }\end{array}$ & [46] \\
\hline $\begin{array}{l}\text { essential gene } \\
\text { screening }\end{array}$ & E. coli & PTasRNA & 152 targets & $P_{\text {trc }}$ & near Tss & paired-termini & $T_{\text {rrnB }}$ & no & $\begin{array}{l}\text { in case of fusA, } 12 \text {-fold } \\
\text { sensitization }\end{array}$ & [77] \\
\hline $\begin{array}{l}\text { actinorhodin } \\
\text { production }\end{array}$ & $\begin{array}{l}\text { S. } \\
\text { coelicolor }\end{array}$ & PTasRNA & actl-ORF1 & $P_{\text {trc }}$ & $\begin{array}{l}\text { 155bp (-92 to } \\
+63) \text { of actl-ORF1 }\end{array}$ & paired-termini & $T_{\text {rrnB }}$ & no & $\begin{array}{l}\text { 4-fold reduction in } \\
\text { actinorhodin production }\end{array}$ & [66] \\
\hline acetone production & $\begin{array}{l}\text { C. aceto- } \\
\text { butylicum }\end{array}$ & $\begin{array}{l}\text { asRNA based on } \\
\text { secondary } \\
\text { structure of } \\
\text { target mRNA }\end{array}$ & ctfA, ctfB & $P_{\text {thl }}$ & $\begin{array}{l}\text { RBS and } \\
\text { structural } \\
\text { subunits }\end{array}$ & $\mathrm{N} / \mathrm{A}$ & $\mathrm{N} / \mathrm{A}$ & no & $\begin{array}{l}\text { 8-fold decrease in acetone } \\
\text { production }\end{array}$ & [78] \\
\hline scaffold engineering & E. coli & $\begin{array}{l}\text { Natural sRNA- } \\
\text { derived scaffolds }\end{array}$ & $\begin{array}{l}\text { TaRNA, } \\
\text { pT181sRNA }\end{array}$ & $P_{\text {araBAD }}$ & RBS and 5'UTR & MicF, Spot42 & $\mathrm{T} 1 / \mathrm{TE}$ & yes & $\begin{array}{l}\text { 28-fold (TaRNA-M icF)/ } 7.7 \\
\text { fold (pT181sRNA-spot42) }\end{array}$ & [60] \\
\hline $\begin{array}{l}\text { automated design of } \\
\text { synthetic SRNA }\end{array}$ & E. coli & $\begin{array}{l}\text { synthetic sRNA } \\
\text { based on } \\
\text { computational } \\
\text { algorithm }\end{array}$ & GFP & $\mathrm{P}_{\text {LacO }}$ & $\begin{array}{l}5^{\prime} U T R \text { containing } \\
\text { region }\end{array}$ & $\begin{array}{l}\text { SokC, FinP, } \\
\text { and DsrA } \\
\text { structure }\end{array}$ & $\mathrm{N} / \mathrm{A}$ & yes & 1-4\% repression & [79] \\
\hline $\begin{array}{l}\text { activation of suicide by } \\
\text { targeting antitoxin }\end{array}$ & E. coli & PNA & $\begin{array}{l}\text { hok mRNA:: } \\
\text { sokRNA } \\
\text { interaction }\end{array}$ & natural & $\begin{array}{l}5 \text { ' region of sok } \\
\text { RNA }\end{array}$ & $\mathrm{N} / \mathrm{A}$ & $\mathrm{N} / \mathrm{A}$ & no & $\begin{array}{l}\text { inhibition of Sok mediated } \\
\text { repression of hok mRNA }\end{array}$ & [9] \\
\hline
\end{tabular}

\footnotetext{
Notes ${ }^{1}$ E.coli Hfq overexpressed under $\mathrm{P}_{\mathrm{hbs}}$ ${ }^{2}$ commonly used multi-domain scaffold (displayed in Figure 2A) ${ }^{3}$ could be others (unknown)
} 


\section{References}

1. Storz G, Vogel J, Wassarman KM : Regulation by small RNAs in bacteria: expanding frontiers. Mol. Cell 2011, 43:880-91. doi: 10.1016/j.molcel.2011.08.022

2. Chappell J, Takahashi MK, M eyer S, Loughrey D, Watters KE, Lucks J: The centrality of RNA for engineering gene expression. Biotechnol. J. 2013, 8:1379-95. doi: 10.1002/biot.201300018

3. Vazquez-Anderson J, Contreras LM : Regulatory RNAs: Charming gene management styles for synthetic biology applications. RNA Biol. 2013, 10:1778-1797. doi: 10.4161/rna.27102

-4. Kang Z, Zhang C, Zhang J, Jin P, Zhang J, Du G, Chen J: Small RNA regulators in bacteria: powerful tools for metabolic engineering and synthetic biology. Appl. M icrobiol. Biotechnol. 2014, 98:3413-24. doi: 10.1007/s00253-014-5569-y

A review of bacterial regulatory RNA mechanisms and applications including riboswitches.

-5. Qi LS, Arkin AP: A versatile framework for microbial engineering using synthetic non-coding RNAs. Nat. Rev. M icrobiol. 2014, 12:341-54. doi: 10.1038/nrmicro3244

A review of ncRNA strategies for strain engineering of bacteria and yeast.

6. M ellin JR, Cossart P: Unexpected versatility in bacterial riboswitches. Trends Genet. 2015, 31:150-156. doi: 10.1016/j.tig.2015.01.005

7. Chaudhary AK, Na D, Lee EY: Rapid and high-throughput construction of microbial cell-factories with regulatory noncoding RNAs. Biotechnol. Adv. 2015, [no volume]. doi:

10.1016/j.biotechadv.2015.05.009

8. Papenfort K, Vanderpool CK: Target activation by regulatory RNAs in bacteria. FEM S M icrobiol. Rev. 2015, 39:362-378. doi: 10.1093/femsre/fuv016

9. Faridani OR, Nikravesh A, Pandey DP, Gerdes K, Good L: Competitive inhibition of natural antisense Sok-RNA interactions activates Hok-mediated cell killing in Escherichia coli. Nucleic Acids Res. 2006, 34:5915-22. doi: 10.1093/nar/gkl750

10. Gelderman G, Contreras LM : Discovery of posttranscriptional regulatory RNAs using next generation sequencing technologies. In Systems M etabolic Engineering: M ethods and Protocols. Edited by Alper HS. Humana Press; 2013:269-95. doi: 10.1007/978-1-62703-299-5

11. Tsai C-H, Liao R, Chou B, Palumbo M, Contreras LM : Genome-wide analysis in bacteria show small RNA enrichment for long and conserved intergenic regions. ]. Bacteriol. 2014, [no volume]. doi: 10.1128/JB.02359-14

12. Van Assche E, Van Puyvelde S, Vanderleyden J, Steenackers HP: RNA-binding proteins involved in post-transcriptional regulation in bacteria. Front. M icrobiol. 2015, 6:141. doi:

10.3389/fmicb.2015.00141 
13. Sauer E: Structure and RNA-binding properties of the bacterial LSm protein Hfq. RNA Biol. 2013, 10:610-8. doi: 10.4161/rna.24201

14. Sobrero P, Valverde C: The bacterial protein Hfq: much more than a mere RNA-binding factor. Crit. Rev. M icrobiol. 2012, 38:276-299. doi: 10.3109/1040841X.2012.664540

••15. Gaida SM , Al-Hinai M A, Indurthi DC, Nicolaou SA, Papoutsakis ET: Synthetic tolerance: three noncoding small RNAs, DsrA, ArcZ and RprA, acting supra-additively against acid stress. Nucleic Acids Res. 2013, 41:8726-8737. doi: 10.1093/nar/gkt651

Three natural ncRNAs overexpressed in combination to achieve 8500-fold improvement of E. coli survival in acid stress.

16. Weber H, Polen T, Heuveling J, Wendisch VF, Hengge R: Genome-wide analysis of the general stress response network in Escherichia coli: sigmaS-dependent genes, promoters, and sigma factor selectivity. J. Bacteriol. 2005, 187:1591-603. doi: 10.1128/JB.187.5.1591-1603.2005

17. Dong T, Schellhorn HE: Role of RpoS in Virulence of Pathogens. Infect. Immun. 2009, 78:887897. doi: 10.1128/IAI.00882-09

18. Battesti A, Majdalani N, Gottesman S: The RpoS-mediated general stress response in Escherichia coli. Annu. Rev. M icrobiol. 2011, 65:189-213. doi: 10.1146/annurev-micro-090110-102946

19. D'Alia D, Nieselt K, Steigele S, M üller J, Verburg I, Takano E: Noncoding RNA of glutamine synthetase I modulates antibiotic production in Streptomyces coelicolor A3(2). J. Bacteriol. 2010, 192:1160-4. doi: 10.1128/JB.01374-09

-20. Li F, Wang Y, Gong K, Wang Q, Liang Q, Qi Q: Constitutive expression of RyhB regulates the heme biosynthesis pathway and increases the 5-aminolevulinic acid accumulation in Escherichia coli. FEM S M icrobiol. Lett. 2014, 350:209-15. doi: 10.1111/1574-6968.12322

Natural ncRNA overexpression achieves 16\% increase in 5-aminolevulinic acid production after traditional metabolic engineering methods failed.

21. Massé E, Salvail H, Desnoyers G, Arguin M : Small RNAs controlling iron metabolism. Curr. Opin. M icrobiol. 2007, 10:140-5. doi: 10.1016/j.mib.2007.03.013

22. Modi SR, Camacho DM, Kohanski M A, Walker GC, Collins JJ: Functional characterization of bacterial sRNAs using a network biology approach. Proc. Natl. Acad. Sci. 2011, 108:1552215527. doi: 10.1073/pnas.1104318108

23. Papenfort K, Pfeiffer V, Lucchini S, Sonawane A, Hinton JCD, Vogel J: Systematic deletion of Salmonella small RNA genes identifies CyaR, a conserved CRP-dependent riboregulator of OmpX synthesis. M ol. M icrobiol. 2008, 68:890-906. doi: 10.1111/j.1365-2958.2008.06189.x 
24. Mars RAT, Nicolas P, Ciccolini M, Reilman E, Reder A, Schaffer M, Mäder U, Völker U, van Dijl JM, Denham EL: Small Regulatory RNA-Induced Growth Rate Heterogeneity of Bacillus subtilis. PLoS Genet. 2015, 11:e1005046. doi: 10.1371/journal.pgen.1005046

25. M ichaux C, Hartke A, M artini C, Reiss S, Albrecht D, Budin-Verneuil A, Sanguinetti M, Engelmann $\mathrm{S}$, Hain $\mathrm{T}$, Verneuil N, et al.: Involvement of Enterococcus faecalis small RNAs in stress response and virulence. Infect. Immun. 2014, 82:3599-611. doi: 10.1128/IAI.01900-14

26. Mann B, van Opijnen T, Wang J, Obert C, Wang Y-D, Carter R, M cGoldrick DJ, Ridout G, Camilli A, Tuomanen El, et al.: Control of Virulence by Small RNAs in Streptococcus pneumoniae. PLoS Pathog. 2012, 8:e1002788. doi: 10.1371/journal.ppat.1002788

27. Caldelari I, Chao Y, Romby P, Vogel J: RNA-Mediated Regulation in Pathogenic Bacteria. Cold Spring Harb. Perspect. M ed. 2013, 3:a010298-a010298. doi: 10.1101/cshperspect.a010298

28. Gripenland J, Netterling S, Loh E, Tiensuu T, Toledo-Arana A, Johansson J: RNAs: regulators of bacterial virulence. Nat. Rev. M icrobiol. 2010, 8:857-866. doi: 10.1038/nrmicro2457

29. Papenfort K, Vogel J: Regulatory RNA in Bacterial Pathogens. Cell Host M icrobe 2010, 8:116-127. doi: 10.1016/j.chom.2010.06.008

30. M ellin JR, Cossart $P$ : The non-coding RNA world of the bacterial pathogen Listeria monocytogenes. RNA Biol. 2012, 9:372-378. doi: 10.4161/rna.19235

31. Haning K, Cho SH, Contreras LM : Small RNAs in mycobacteria: an unfolding story. Front. Cell. Infect. M icrobiol. 2014, 4. doi: 10.3389/fcimb.2014.00096

32. Sonnleitner E, Romeo A, Bläsi U: Small regulatory RNAs in Pseudomonas aeruginosa. RNA Biol. 2012, 9:364-371. doi: 10.4161/rna.19231

33. Tomasini A, François $P$, Howden BP, Fechter $P$, Romby $P$, Caldelari I: The importance of regulatory RNAs in Staphylococcus aureus. Infect. Genet. Evol. 2014, 21:616-626. doi: 10.1016/j.meegid.2013.11.016

34. Wilton J, Acebo P, Herranz C, Gómez A, Amblar M : Small regulatory RNAs in Streptococcus pneumoniae: discovery and biological functions. Front. Genet. 2015, 6:126. doi: 10.3389/fgene.2015.00126

35. Bardill JP, Hammer BK: Non-coding sRNAs regulate virulence in the bacterial pathogen Vibrio cholerae. RNA Biol. 2012, 9:392-401. doi: 10.4161/rna.19975

36. Mizuno $T$, Chou MY, Inouye $M$ : A unique mechanism regulating gene expression: translational inhibition by a complementary RNA transcript (micRNA). Proc. Natl. Acad. Sci. 1984, 81:19661970. doi: 10.1073/pnas.81.7.1966 
37. Coleman J, Green PJ, Inouye M : The use of RNAs complementary to specific mRNAs to regulate the expression of individual bacterial genes. Cell 1984, 37:429-436. doi: 10.1016/00928674(84)90373-8

38. Pestka S, Daugherty BL, Jung V, Hotta K, Pestka RK: Anti-mRNA: specific inhibition of translation of single mRNA molecules. Proc. Natl. Acad. Sci. 1984, 81:7525-7528. doi:

$10.1073 /$ pnas. 81.23 .7525

39. Kaur P, Agarwal S, Datta S: Delineating bacteriostatic and bactericidal targets in mycobacteria using IPTG inducible antisense expression. PLoS One 2009, 4: e5923. doi: 10.1371/journal.pone.0005923

40. Parish T, Stoker NG: Development and use of a conditional antisense mutagenesis system in mycobacteria. FEM S M icrobiol. Lett. 2006, 154:151-157. doi: 10.1111/j.15746968.1997.tb12637.x

41. Desai RP, Papoutsakis ET: Antisense RNA Strategies for Metabolic Engineering of Clostridium acetobutylicum. Appl. Envir. M icrobiol. 1999, 65:936-945.

42. Ji Y, Zhang B, Van SF, Horn, Warren P, Woodnutt G, Burnham M K, Rosenberg M : Identification of critical staphylococcal genes using conditional phenotypes generated by antisense RNA. Science 2001, 293:2266-9. doi: 10.1126/science.1063566

43. Bouazzaoui K, LaPointe G: Use of antisense RNA to modulate glycosyltransferase gene expression and exopolysaccharide molecular mass in Lactobacillus rhamnosus. J. M icrobiol. M ethods 2006, 65:216-25. doi: 10.1016/j.mimet.2005.07.011

44. Biedendieck R, M alten M, Barg H, Bunk B, Martens J-H, Deery E, Leech H, Warren MJ, Jahn D: Metabolic engineering of cobalamin (vitamin B12) production in Bacillus megaterium. M icrob. Biotechnol. 2010, 3:24-37. doi: 10.1111/j.1751-7915.2009.00125.x

45. Nakashima N, M iyazaki K: Bacterial cellular engineering by genome editing and gene silencing. Int. J. Mol. Sci. 2014, 15:2773-93. doi: 10.3390/ijms15022773

46. Nakashima N, Tamura T, Good L: Paired termini stabilize antisense RNAs and enhance conditional gene silencing in Escherichia coli. Nucleic Acids Res. 2006, 34:e138. doi: 10.1093/nar/gkl697

- 47. Yoo SM, Na D, Lee SY: Design and use of synthetic regulatory small RNAs to control gene expression in Escherichia coli. Nat. Protoc. 2013, 8:1694- 707. doi: 10.1038/nprot.2013.105

Detailed protocol of synthetic multi-domain scaffold ncRNA design and use for gene expression control.

48. Man S, Cheng R, M iao C, Gong Q, Gu Y, Lu X, Han F, Yu W: Artificial trans-encoded small noncoding RNAs specifically silence the selected gene expression in bacteria. Nucleic Acids Res. 2011, 39:e50. doi: 10.1093/nar/gkr034 
-49. Nakashima N, Ohno S, Yoshikawa K, Shimizu H, Tamura T: A vector library for silencing central carbon metabolism genes with antisense RNAs in Escherichia coli. Appl. Environ. M icrobiol. 2014, 80:564-73. doi: 10.1128/AEM .02376-13

Paired-termini synthetic ncRNA screen of 71 mRNA targets for knockdown achieves pyruvate production in E. coli equivalent to traditional metabolic engineering strains.

50. Nakashima N, Tamura T: Gene silencing in Escherichia coli using antisense RNAs expressed from doxycycline-inducible vectors. Lett. Appl. M icrobiol. 2013, 56:436-42. doi: 10.1111/lam.12066

51. Nakashima N, Tamura T: Conditional gene silencing of multiple genes with antisense RNAs and generation of a mutator strain of Escherichia coli. Nucleic Acids Res. 2009, 37:e103. doi: 10.1093/nar/gkp498

-52. Libis VK, Bernheim AG, Basier C, Jaramillo-Riveri S, Deyell M, Aghoghogbe I, Atanaskovic I, Bencherif AC, Benony M, Koutsoubelis N, et al.: Silencing of Antibiotic Resistance in E. coli with Engineered Phage Bearing Small Regulatory RNAs. ACS Synth. Biol. 2014, 3:1003-6. doi: $10.1021 /$ sb500033d

Synthetic ncRNAs may be delivered by phage transfection as shown in this example of engineering antibiotic resistance of $\mathrm{E}$. coli.

53. Sharma V, Yamamura A, Yokobayashi Y: Engineering artificial small RNAs for conditional gene silencing in Escherichia coli. ACS Synth. Biol. 2012, 1:6-13. doi: 10.1021/sb200001q

54. Sharma V, Sakai Y, Smythe KA, Yokobayashi Y: Knockdown of recA gene expression by artificial small RNAs in Escherichia coli. Biochem. Biophys. Res. Commun. 2013, 430:256-9. doi: 10.1016/j.bbrc.2012.10.141

55. Busch A, Richter AS, Backofen R: IntaRNA: efficient prediction of bacterial sRNA targets incorporating target site accessibility and seed regions. Bioinformatics 2008, 24:2849-56. doi: 10.1093/bioinformatics/btn544

• 56. Na D, Yoo SM, Chung H, Park H, Park JH, Lee SY: Metabolic engineering of Escherichia coli using synthetic small regulatory RNAs. Nat. Biotechnol. 2013, 31:170-174. doi: 10.1038/nbt.2461

Synthetic multi-domain scaffold ncRNAs are developed and used for large-scale target identification in the pathways of interest (tyrosine and cadaverine production) and to knockdown effective targets for strain engineering.

57. Yoo SM, Na D, Lee SY: Design and use of synthetic regulatory small RNAs to control gene expression in Escherichia coli. Nat. Protoc. 2013, 8:1694-707. doi: 10.1038/nprot.2013.105

58. Choi YJ, Lee SY: M icrobial production of short-chain alkanes. Nature 2013, 502:571-4. doi: 10.1038 / nature12536 
59. Kim B, Park H, Na D, Lee SY: Metabolic engineering of Escherichia coli for the production of phenol from glucose. Biotechnol. J. 2014, 9:621-9. doi: 10.1002/ biot.201300263

60. Sakai Y, Abe K, Nakashima S, Yoshida W, Ferri S, Sode K, Ikebukuro K: Improving the GeneRegulation Ability of Small RNAs by Scaffold Engineering in Escherichia coli. ACS Synth. Biol. 2014, 3:152-162. doi: 10.1021/sb4000959

61. Pain A, Ott A, Amine H, Rochat T, Bouloc P, Gautheret D: An Assessment of Bacterial Small RNA Target Prediction Programs. RNA Biol. 2015, [no volume]. doi: 10.1080/ 15476286.2015.1020269

-62. Liu Y, Zhu Y, Li J, Shin H, Chen RR, Du G, Liu L, Chen J: Modular pathway engineering of Bacillus subtilis for improved $\mathrm{N}$-acetylglucosamine production. M etab. Eng. 2014, 23:42-52. doi: 10.1016/j.ymben.2014.02.005

First ncRNA engineering strategy in B. subtilis demonstrates generalizibilty of standard blueprints by sucessfully increasing $\mathrm{N}$-acetylglucosamine production by $134 \%$.

63. Wu J, Yu O, Du G, Zhou J, Chen J: Fine-tuning of the fatty acid pathway by synthetic antisense RNA for enhanced (2S)-naringenin production from L-tyrosine in Escherichia coli. Appl. Environ. M icrobiol. 2014, 80:7283-7292. doi: 10.1128/AEM .02411-14

64. Wu J, Zhou T, Du G, Zhou J, Chen J: M odular optimization of heterologous pathways for de novo synthesis of (2S)-naringenin in Escherichia coli. PLoS One 2014, 9:e101492. doi:

10.1371/journal.pone.0101492

65. Patil SD, Sharma R, Srivastava S, Navani NK, Pathania R: Downregulation of yidC in Escherichia coli by antisense RNA expression results in sensitization to antibacterial essential oils eugenol and carvacrol. PLoS One 2013, 8:e57370. doi: 10.1371/journal.pone.0057370

66. Uguru GC, M ondhe M, Goh S, Hesketh A, Bibb MJ, Good L, Stach JEM : Synthetic RNA Silencing of Actinorhodin Biosynthesis in Streptomyces coelicolor A3(2). PLoS One 2013, 8:e67509. doi: 10.1371/journal.pone.0067509

67. Chappell J, Takahashi MK, Lucks JB: Creating small transcription activating RNAs. Nat. Chem. Biol. 2015, advance on. doi: 10.1038/nchembio.1737

68. Isaacs FJ, Dwyer DJ, Ding C, Pervouchine DD, Cantor CR, Collins JJ: Engineered riboregulators enable post-transcriptional control of gene expression. Nat. Biotechnol. 2004, 22:841-7. doi: $10.1038 / \mathrm{nbt} 986$

69. Sowa SW, Vazquez-Anderson J, Clark CA, De La Peña R, Dunn K, Fung EK, Khoury MJ, Contreras LM : Exploiting post-transcriptional regulation to probe RNA structures in vivo via fluorescence. Nucleic Acids Res. 2015, 43:e13. doi: 10.1093/nar/gku1191

70. Benenson Y: RNA-based computation in live cells. Curr. Opin. Biotechnol. 2009, 20:471-8. doi: 10.1016/j.copbio.2009.08.002 
71. Dambach M , Irnov I, Winkler WC: Association of RNAs with Bacillus subtilis Hfq. PLoS One 2013, 8:e55156. doi: 10.1371/journal.pone.0055156

72. Rouskin S, Zubradt M, Washietl S, Kellis M, Weissman JS: Genome-wide probing of RNA structure reveals active unfolding of mRNA structures in vivo. Nature 2014, 505:701-5. doi: 10.1038 / nature 12894

73. Loughrey D, Watters KE, Settle AH, Lucks JB: SHAPE-Seq 2.0: systematic optimization and extension of high-throughput chemical probing of RNA secondary structure with next generation sequencing. Nucleic Acids Res. 2014, 42:e165- doi: 10.1093/nar/gku909

74. Kemmer C, Neubauer P: Antisense RNA based down-regulation of RNaseE in E. coli. Microb. Cell Fact. 2006, 5:38. doi: 10.1186/1475-2859-5-38

75. Jin Y, Wu J, Li Y, Cai Z, Huang J-D: Modification of the RpoS network with a synthetic small RNA. Nucleic Acids Res. 2013, 41:8332-40. doi: 10.1093/nar/gkt604

76. Chen $Y, X u$ D, Fan $L$, Zhang $X$, Tan T: Manipulating multi-system of NADPH regulation in Escherichia coli for enhanced S-adenosylmethionine production. RSC Adv. 2015, 5:4110341111. doi: 10.1039/C5RA02937F

77. Meng J, Kanzaki G, M eas D, Lam CK, Crummer H, Tain J, Xu HH: A genome-wide inducible phenotypic screen identifies antisense RNA constructs silencing Escherichia coli essential genes. FEM S M icrobiol. Lett. 2012, 329:45-53. doi: 10.1111/j.1574-6968.2012.02503.x

78. Tummala SB, Welker NE, Papoutsakis ET: Design of Antisense RNA Constructs for Downregulation of the Acetone Formation Pathway of Clostridium acetobutylicum. J. Bacteriol. 2003, 185:1923-1934. doi: 10.1128/JB.185.6.1923-1934.2003

79. Rodrigo G, Landrain TE, Shen S, Jaramillo A: A new frontier in synthetic biology: automated design of small RNA devices in bacteria. Trends Genet. 2013, 29:529-36. doi:

10.1016/j.tig.2013.06.005 


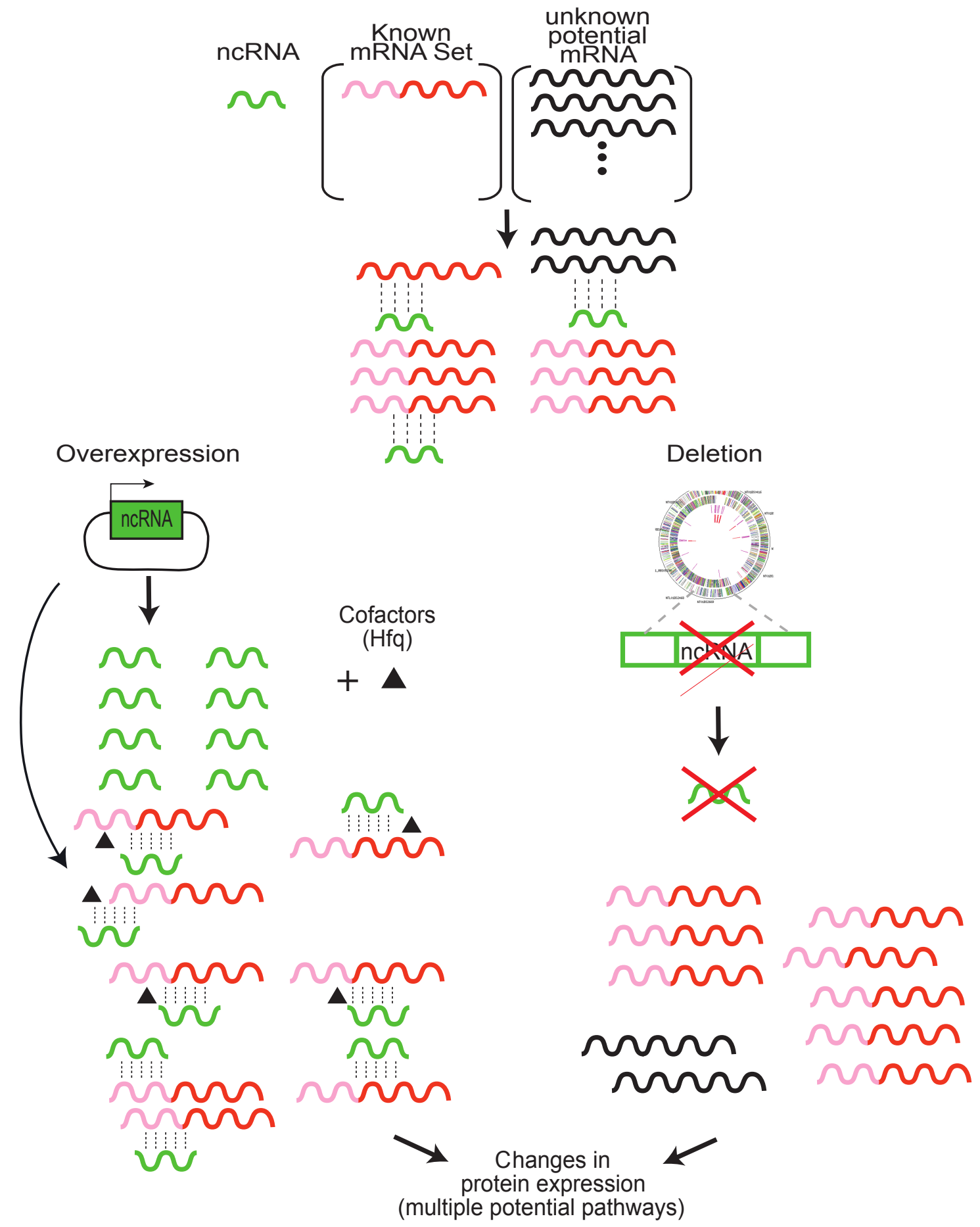

$\downarrow$

nn

nn nn nn num unn nn
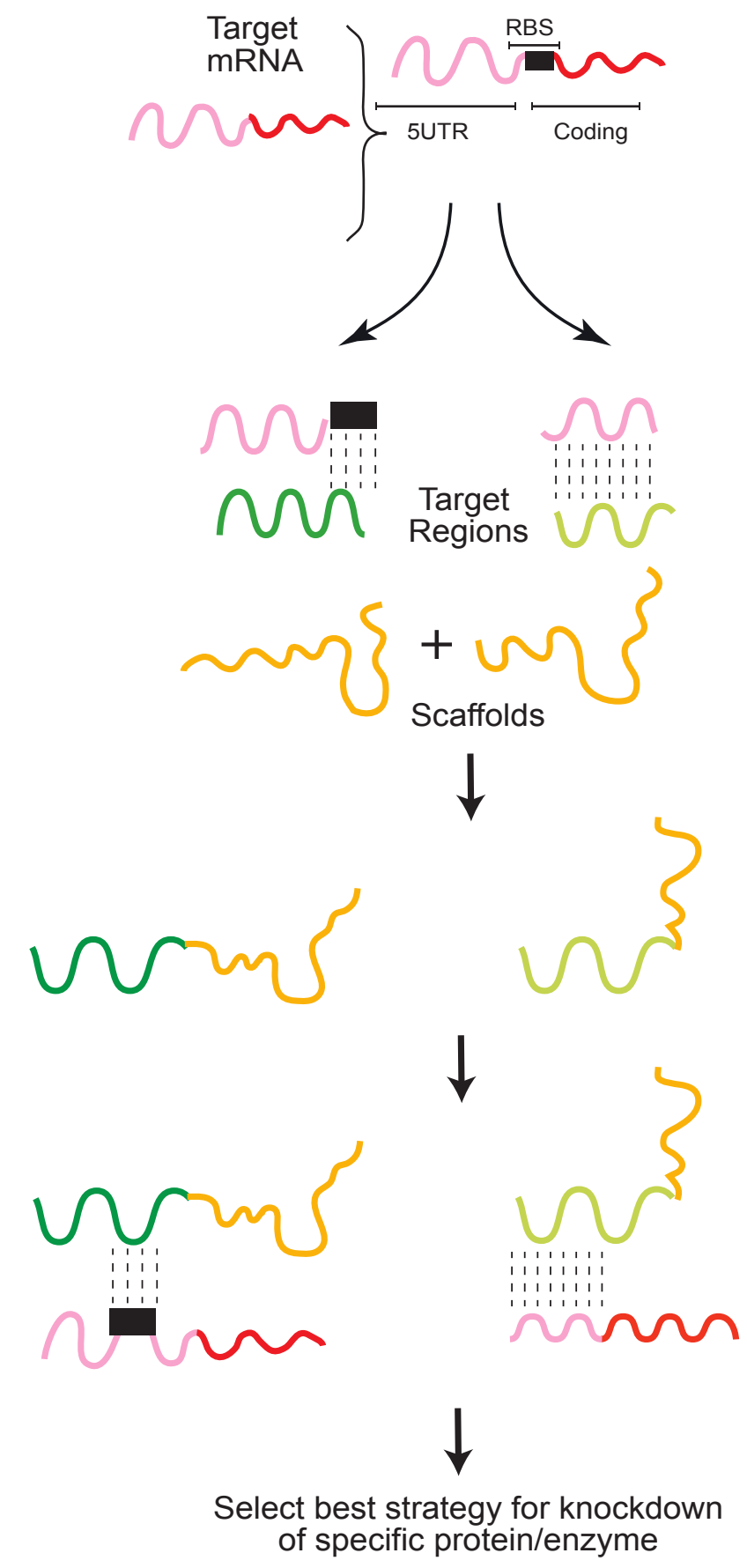
A Synthetic multi-domain scaffold

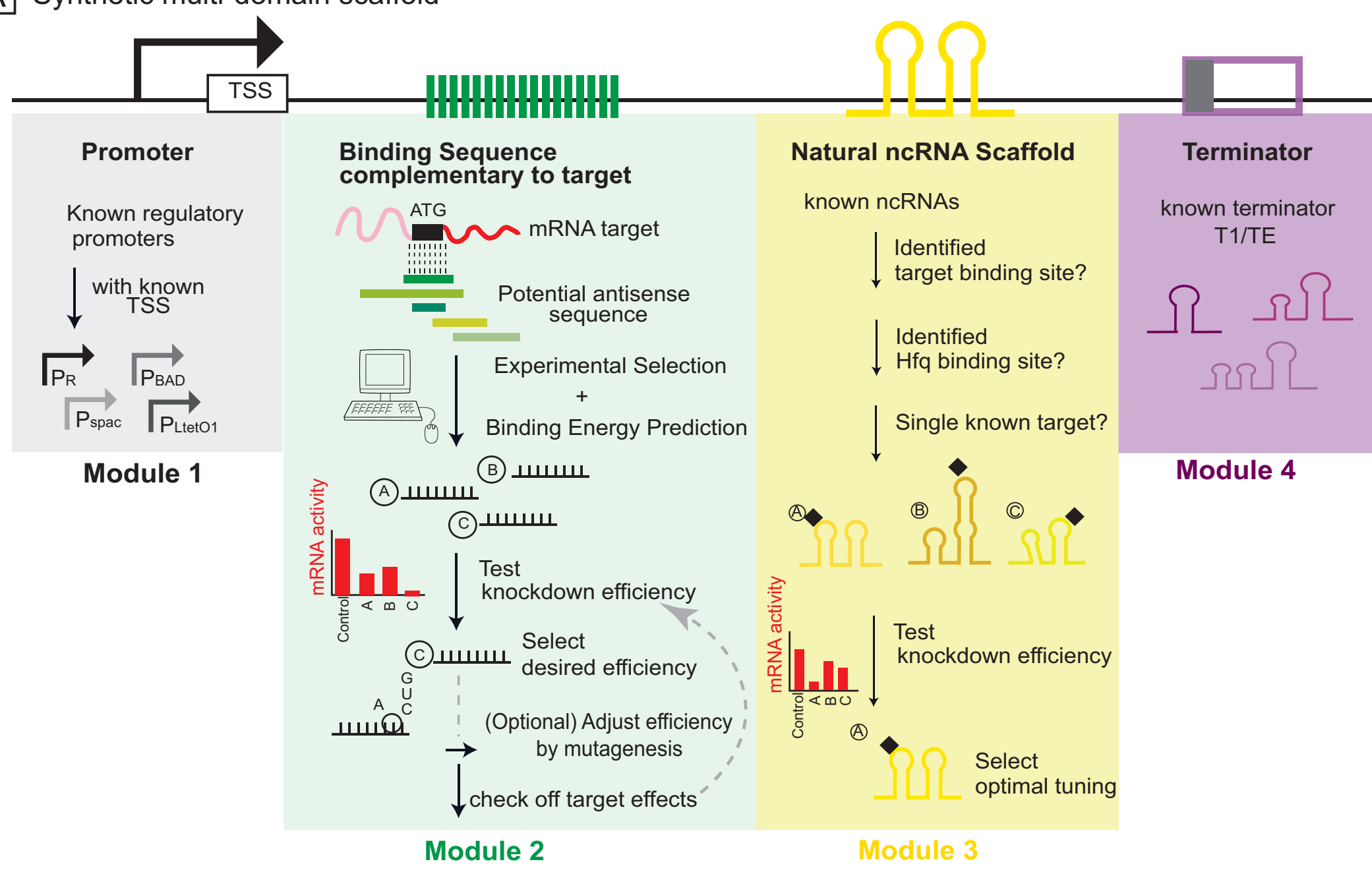

B Paired-termini antisense RNA (PTasRNA)

Module 1

\section{Promoter}

Known regulatory promoters

$\downarrow$ with known

$\overrightarrow{P_{\text {trc }}} \underset{\mathrm{PBAD}_{\mathrm{B}}}{\overrightarrow{\mathrm{N}}}$<smiles>C1CC(C2CC2)[Te]1</smiles>

Module 2

Binding Sequence complementary to target

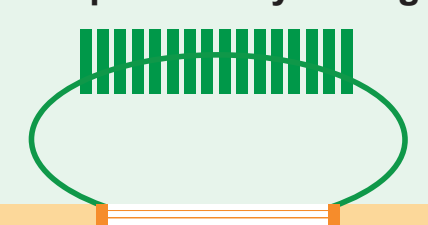

\section{Module 3}

Paired-termini

$38 \mathrm{bp}$ inverted repeat creating double-stranded RNA termini

5 ' GCACCACCACCACCACCAC UGCAUGgUUAAUUCCUCCU 3 '
Module 4

\section{Terminator}

known terminator

$$
\text { TrrnB }
$$

\section{$38 \mathrm{bp}$ inverted repeat}

creating double-stranded

RNA termini

5 ' AGGAGGAAUUAACCAUGCA GUGGUGGUGGUGGUGGUGC 3 '

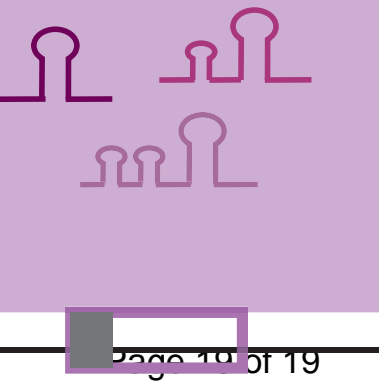

